\title{
Notas sobre ser beneficiário, ser demandatário: processos de subjetivação na Política de Assistência Social
}

\author{
Notes on being either a beneficiary or a demander: subjectivations processes in the Social \\ Assistance Policy
}

\author{
Suzanir Fernanda Maia* \\ Anita Guazzelli Bernardes**
}

\section{Resumo:}

O objetivo deste artigo consiste em aprofundar os conceitos de beneficiário e demandatário das Políticas Sociais de Assistência Social, com vistas a problematizar o modo como estes sujeitos circulam e são vistos nas Políticas Sociais, de forma a compreender os processos de inclusão social. As figuras do beneficiário e do demandatário que circulam nas Políticas Sociais, faz se ver e falar de modos distintos de acesso e permanência nestas Políticas. O cenário de análise são as Políticas Sociais de Assistência Social que se inscrevem no Brasil, principalmente, a partir da Constituição Federal de 1988. O percurso metodológico utilizado é o cartográfico, onde se dá o encontro com conceitos teóricos e outros materiais que se apresentam no momento mesmo da pesquisa. Com a realização deste estudo, foi possível conectar outras modalidades de compreensão do direito, principalmente quando analisado a partir da benesse.

Palavras-chave: Sujeito de direito; Linhas de fuga; Plano de imanência; Assistência Social; Benesse.

\begin{abstract}
:
The aim of this paper is to deepen the concepts of beneficiary and demander in Social Policies of Social Assistance, aiming to problematize the way that those subjects have circulated and been regarded in Social Policies, to understand the processes of social inclusion. The figures of both the beneficiary and the demander have circulated in Social Policies, generating different ways of accessing and remaining in those Policies. The scenario of analysis comprehends the Social Policies of Social Assistance in Brazil, particularly since 1988 Federal Constitution. The cartographic methodological path brought together the theoretical concepts and other materials that emerged along the research. This study has enabled the connection of other modalities of understanding right, especially when it is analyzed from the perspective of beneficence.
\end{abstract}

Keywords: Subject of rights; Lines of flight; Plane of immanence; Social Assistance; Beneficence.

\footnotetext{
* Pós-doutorado em Psicologia da Saúde pela Universidade Católica Dom Bosco (UCDB).

${ }^{* *}$ Pesquisadora e docente do Programa de Pós-graduação em Psicologia da Saúde da Universidade Católica Dom Bosco (UCDB).
} 


\section{Cartografias da Assistência Social ${ }^{1}$, dos beneficiários e demandatários}

A Política de Assistência Social no Brasil, ao longo das últimas décadas, tem-se constituído como instrumento de possibilidade de acesso a outras Políticas Sociais, bem como tem contribuído para o deslocamento de pessoas em situação de vulnerabilidade para o acesso aos diferentes direitos.

Mesmo primando pelo atendimento "a quem dela necessitar", a Política de Assistência Social foi se moldando a partir de mecanismos de seleção para o atendimento das demandas sociais. Trata-se de mecanismos que delimitam o público-alvo e o caracterizam, na medida em que se multiplicam os inúmeros formulários que os sujeitos devem preencher para o acesso a determinado bem, serviço ou direito.

Nestas múltiplas modalidades de caracterização, os sujeitos da Assistência Social são denominados usuários, demandatários e beneficiários. Sem nenhuma diferenciação teórica/epistemológica entre os termos ora apresentados, estes caracterizam os sujeitos que buscam, por meio da Política de Assistência Social, acessar espaços dos quais estavam à margem. Espaços são entendidos aqui como os direitos que todos têm, juridicamente falando, mas que nem todos conseguem acessar. Espaços também são compreendidos como as territorialidades atendidas pelas diferentes intervenções da Política de Assistência Social, que tenta alcançar diferentes sujeitos, esquadrinhados em faixas etárias ou de renda per capita.

Assim, sujeitos e espaços vão constituir os focos de intervenção dos Serviços ofertados pela Política de Assistência Social. São serviços e bens tidos como públicos, mas que se individualizam na figura de beneficiários e demandatários, uma vez que o conhecimento a respeito dos direitos sociais é acionado por um ou por outro sujeito da Assistência Social.

Neste estudo, beneficiários e demandatários são sujeitos comuns que acessam as diferentes políticas públicas, principalmente aquelas enredadas nas redes da Política de Assistência Social, que se traduzem na oferta de bens, serviços e direitos sociais, mas que também podem ser descritas por meio das (im)possibilidades de acessar ou não estes bens/serviços/direitos.

\footnotetext{
1 Trata-se de uma cartografia social que "Diferentemente da cartografia tradicional, que traça mapas de territórios, relevo e distribuição populacional, uma cartografia social faz diagramas de relações, enfrentamentos e cruzamentos entre forças, agenciamentos, jogos de verdade, enunciações, jogos de objetivação e subjetivações, produções e estetizações de si mesmo, práticas de resistência e liberdade. Como método presta-se a análise e desmontagem de dispositivos, ação que consiste em desemaranhar suas enredadas linhas, além de instrumentalizar a resistência a seus modos de objetivação e subjetivação (PRADO FILHO; TETI, 2013, p. 45).

Este artigo contou com financiamento do CNPq e da CAPES.
} 
Colocar a Política de Assistência Social e seus usuários/beneficiários/demandatários em análise permite fazer alguns questionamentos. O primeiro deles é sobre a utilização de diferentes termos para identificar o sujeito que acessa a Política de Assistência Social. Constituem termos específicos para diferentes sujeitos ou referem-se a um único sujeito? Colocar as designações em análise, a partir dessa pergunta, significa situar que a forma como se designa, aproximando palavras/coisas/sujeitos, produz realidades e, sobretudo, se refere a uma estratégia política de produção de objetos e subjetividades que implicam os modos como habita-se e circula-se nos espaços. Portanto, colocar em análise as formas de identificar os sujeitos na Assistência Social é percorrer um caminho em que se problematiza a própria Assistência Social e os modos como se constitui em termos de estratégias de governo da vida.

Para refletir sobre estas questões, retomam-se os conceitos de Sujeito de Direito e Homo oeconomicus, consolidados por Foucault (2008), bem como as análises da tese Problematizando o acesso às Políticas Sociais no campo da Educação Superior (MAIA, 2018), em que se aproxima o sujeito de direito do beneficiário, e o Homo oeconomicus do demandatário. Trata-se de um esforço, não de colocar em evidência os conceitos sobre estes sujeitos, mas de problematizar a possibilidade de que beneficiários e demandatários sejam entendidos a partir de processos de subjetivação que permitem acesso aos diferentes direitos sociais no âmbito das Políticas Sociais, em especial, a Política de Assistência Social.

É importante destacar que não é objetivo desta análise transpor conceitos ao longo do tempo, como se eles fossem imutáveis e estivessem presentes do mesmo modo, em qualquer tempo-espaço da história. Ao contrário, objetiva-se verificar como estes conceitos se atualizam e se constituem como modos de subjetivação e ressignificação dos sujeitos que acessam a Política de Assistência Social em seus diferentes níveis de intervenção.

Assim, ao atualizar os tempos-espaços em que circulam sujeitos de direito e Homo oeconomicus, é possível também estabelecer relações entre estes e a Política de Assistência Social, considerando não somente os processos de subjetivação que envolvem estas relações, mas, sobretudo, as diferentes modalidades de atualização do sujeito para o acesso ao direito no que tange aos modos de governo dos vivos.

Em que pesem inúmeras vertentes nas quais se consolidam os direitos sociais no Brasil, para este momento, o tempo-espaço de análise inicia-se com a promulgação da Constituição Federal de 1988. É a partir dela que a Assistência Social toma forma de Política Pública, logo, de responsabilidade do Estado. 
Trazer a Política de Assistência Social para o patamar de Política Pública implicou diferentes processos de reconfiguração dos direitos (mais conhecidos como bens e serviços) disponibilizados nesta Política. Assim, a

[...] política de assistência social, que, por ser a última política social regulamentada no século XX, possibilita decifrar as heranças presentes na compreensão da efetivação dos direitos, especialmente os sociais. Ou seja, a forma como essa política foi incorporada no Brasil permite, além da compreensão de como foram concebidos e gestados os direitos, a reflexão sobre os desafios no sentido da construção de um sistema de proteção social que leve em consideração de fato o amplo espectro da cidadania (COUTO, 2006, p. 29).

O processo de consolidação e afirmação desta Política como dever do Estado decorre de múltiplos jogos de poder que se estabeleceram entre as reivindicações apresentadas pela população via movimentos sociais e a disponibilidade do Estado em incluir estas demandas em sua agenda política.

Ao revisar o contexto histórico da Política de Assistência Social no Brasil, é possível evidenciar uma "matriz genética" cunhada em ações da benesse e da caridade. Sem normativas específicas, a assistência social deu-se ao longo do tempo por diferentes modalidades de atendimento, sem controle específico do Estado nas intervenções voltadas para aqueles que se encontravam em situação de vulnerabilidade socioeconômica:

\begin{abstract}
A subsistência da mão de obra escrava e dos trabalhadores livres [em meados de 1824], porém submetidos aos grandes proprietários, era responsabilidade destes proprietários. $\mathrm{O}$ trabalho com os que ficavam à margem dessa realidade era feito pelos religiosos, sem interferência do Estado, criando-se, a partir dessa época, as condições para a caracterização dessa área como campo da filantropia ou da iniciativa de cunho privado. $O$ tratamento ao povo que reclamava por atendimento às suas demandas era feito por intermédio de mecanismos ora de privilégios, ora de repressão, fenômenos estes historicamente presentes na sociedade. Se era de interesse do projeto da elite nacional, havia um movimento para sua concessão; caso contrário, a repressão era utilizada como instrumento de desmonte dos movimentos pela garantia dos mesmos (COUTO, 2006, p. 87-89).
\end{abstract}

Quer seja pela via do atendimento aos doentes pelas Santas Casas de Misericórdia, quer seja pelas ações de "doação" realizadas pelas primeiras-damas, a Assistência Social tinha um papel específico, que era o de possibilitar que os pobres fossem atendidos precariamente, para que as sociedades burguesas pudessem "salvar suas almas".

Quando a Assistência Social se consolida como Política Pública, relaciona-se intrinsecamente com o Trabalho Formal, de modo que só poderiam acessar a Política de Assistência Social aqueles que estivessem inseridos no mercado de trabalho formal. Aos 
demais, restariam ainda ações de cunho beneficente das igrejas e das primeiras-damas. Assim, em meados de 1930:

\begin{abstract}
Passaram a ser critérios de inclusão ou exclusão nos benefícios sociais a posição ocupacional e o rendimento auferido. Estes critérios colocaram somente os trabalhadores urbanos em posição de privilégio, pois sua vinculação ao mercado formal de trabalho era a garantia de inserção nas políticas sociais da época. Esse corte de inclusão deu-se ainda numa realidade onde a maioria dos trabalhadores estava vinculada ao trabalho rural e, portanto, desprotegida. As medidas regulatórias criaram um clima favorável ao deslocamento da base produtiva, incentivando a vinda dos trabalhadores rurais para os centros urbanos, em busca de melhores condições de vida. Essa legislação, embora autoritária e controladora, constituiu-se num avanço das relações entre trabalhadores, empregadores e governos, pois partiu de um patamar de inexistência de garantia, característica que demarcava o trabalho rural da época (COUTO, 2006, p. 96).
\end{abstract}

Mesmo se reconfigurando ao longo do tempo como Política Pública, principalmente a partir da Constituição Federal de 1988 e do estabelecimento da Lei Orgânica de Assistência Social (1993), a Política de Assistência Social carrega consigo o rastro da benesse. Este aspecto vai, então, demarcando os usuários/beneficiários/demandatários desta Política. Nos discursos que interpelam os sujeitos da Assistência Social, a "doação" do direito vai tomando o lugar do próprio direito. Assim, o sujeito acessa a Política Social, todavia, nem sempre alcança o direito que lhe cabe.

A precariedade de recursos destinados à Política de Assistência Social vai definindo e limitando seu alcance de intervenção. Dessa forma, não tem acesso à Assistência Social "quem dela necessita", como apregoa a Lei, mas aquele que comprova, com maior intensidade, sua condição de miséria.

Os atendimentos dão-se mediante o preenchimento de extensos formulários, que descrevem, em suas minúcias, a vida de cada um que requer um direito. Tais formulários multiplicam-se em virtude da ampliação de direitos em diferentes contextos da vida da população. Trata-se de direitos impulsionados por jogos de poder dentro e fora da Política de Assistência Social, os quais geram novas possibilidades de acesso, mas por vias cada vez mais restritas.

A Assistência Social vai ganhando corpo e forma com a instituição do Sistema Único de Assistência Social (BRASIL, 2011), que passa a orientar como devem ser realizados os atendimentos em todo o Território Nacional. Esta padronização no atendimento até pode ser reconhecida como um avanço, na medida em que desmobilizou, em grande parte, 
ações/intervenções pessoais com viés de caridade e benesse. Todavia, em que pesem todas as orientações presentes no Sistema Único de Assistência Social, as ações reconhecidas como "ações de primeira-damismo", ou o que foi chamado de "personificação da Assistência Social" (ex.: o prefeito Ihe deu esta casa; a primeira-dama lhe deu este kit enxoval etc.), ainda estão presentes no cotidiano de muitos sujeitos que acessam a Assistência Social no Brasil.

Dessa forma, na análise aqui proposta, evidenciam-se diferentes processos de subjetivação dos sujeitos que acessam a Política de Assistência Social, possibilitando pensar as figuras do beneficiário e do demandatário.

\section{Notas sobre as ontologias de sujeito na Assistência Social}

Ao se colocar o sujeito da Assistência Social sob as modalidades de beneficiário e demandatário, não se tem por objetivo caracterizar sujeitos diferentes, mas analisar processos de subjetivação que permitem acessar diferentes direitos de modos específicos. É, então, o sujeito da assistência um beneficiário e um demandatário. Estas modalidades de subjetivação dão-se pelo modo como o sujeito da Política de Assistência Social se coloca/mobiliza em distintos espaços que as Políticas Sociais, em especial a Política de Assistência Social, Ihe permitem deslocar-se:

É certo que, principalmente a partir do século XVIII, os homens têm travado uma batalha sobre em que consistem os direitos, como identificá-los, como protegê-los e como cobrá-los. E sua assunção tem sido demarcada por movimentos contraditórios, heterogêneos e apontando estágios diferentes, conforme a realidade, os sistemas político, econômico, social e cultural. Por exemplo, se a liberdade religiosa é considerada um direito em muitos países, em alguns seria uma transgressão. Se o acesso à renda, em alguns países desenvolvidos, é considerado legítimo por meio de programas estatais, em outros esse acesso, por essa via, é considerado um entrave ao espírito empreendedor exigido pelo capitalismo (COUTO, 2006, p. 38).

Assim, diferentes deslocamentos de um sujeito permitem-lhe também distintos modos de relacionar-se com a Política de Assistência Social e com todos os direitos que lhe são juridicamente garantidos, mas que lhe são negados diariamente.

No exercício de cartografia sobre o "beneficiário/demandatário" que aparece em distintos momentos de um documento, de uma Política ou de diferentes Políticas Públicas, passa-se a rastrear os significados que se dão às designações a partir das conexões que estabelecem, apoiando na seguinte interrogação: se são utilizados para designar este ou aquele sujeito que tem acesso a determinado bem/serviço/direito, como é que se conceituam estes termos? A primeira busca foi feita em dicionários específicos da Assistência Social 
(FERNANDES, HELLMANN, 2016; BELO HORIZONTE, 2007). Nestes materiais, não foi encontrada a definição para esses verbetes. Definem-se os termos usuários (BELO HORIZONTE, 2007; SILVA, 2016) e público-alvo (BELO HORIZONTE, 2007) como aquele que busca o atendimento ou faz parte do atendimento da referida Política. A definição mais aproximada de demandatário encontrada, considerando aqui a estrutura ortográfica, foi o termo: “Demanda. Manifestação de necessidades apresentadas explicitamente pelo usuário ou identificadas pelo técnico, que exigem intervenções de natureza socioassistencial" (BELO HORIZONTE, 2007, p. 33).

Em suas análises do termo usuário da Assistência Social, Silva (2016) ressalta o estigma que tal designação carrega, tendo em vista que sempre esteve relacionada aos indivíduos em situação de vulnerabilidade e subalternidade, estabelecendo uma relação de dependência dos usuários das ações efetivadas pela Assistência Social. A autora ainda destaca um movimento discreto de alguns operadores da Política de Assistência Social para uma ruptura no modo de reconhecer o usuário de suas intervenções, trazendo o termo demandatário para suas reflexões. Observa-se que não há uma definição específica para o referido termo:

[...] a percepção por parte dos operadores da Política de Assistência Social para esse reconhecimento dos sujeitos demandatários como sujeitos capazes de superar essa condição subalterna, sujeitos capazes de reconstruir suas histórias de vida, de reconhecimento de sua identidade e cidadania por meio do incentivo às lutas contra as desigualdades e a favor da garantia de direitos sociais plenos e universais (SILVA, 2016, p. 293).

As análises de Silva (2016), mesmo que a priori não definam expressamente o termo demandatário, permitem reafirmar a necessidade de se considerar os movimentos que estabelecem novas formas de operar a Política de Assistência Social, incluindo aqui um novo olhar sobre o público-alvo das intervenções desta política.

Na Política Nacional de Assistência Social - PNAS (BRASIL, 2004), não há descrição dos termos beneficiários e demandatários, mas eles "emergem" em diferentes modalidades de acesso a bens e serviços. O termo beneficiário é mais recorrente, destacando-se quando há a descrição do Benefício de Prestação Continuada (BPC) e tendo relação direta com o benefício nesta análise. Já o termo demandatário, no texto da PNAS, aparece uma única vez, relacionando a necessidade de sua identificação por meio da demanda de direitos, bens e serviços integrados na Política de Assistência Social. 


\begin{abstract}
A Assistência Social como política de proteção social configura-se como uma nova situação para o Brasil. Ela significa garantir a todos, que dela necessitam, e sem contribuição prévia a provisão dessa proteção. Esta perspectiva significaria aportar quem, quantos, quais e onde estão os brasileiros demandatários de serviços e atenções de assistência social (BRASIL, 2004, p. 15).
\end{abstract}

Conforma-se, portanto, com as análises preliminares, em que destacou-se a relação direta entre demandatário e demanda. Por meio da "procura" do sujeito por determinados bens, serviços e direitos, ele será o demandatário destas ações na Assistência Social, de tal modo que sua demanda se tornará um dado estatístico, será esquadrinhada em números e, novamente, em outros formulários para acesso efetivo ao que o demandatário demandou.

É também este movimento do demandatário em demandar intervenções específicas, que a produção de outras subjetividades é possível. Demandar, aqui, é mais do que conhecer seus direitos de acesso a bens/serviços/direitos; demandar é também necessitar de algo. Algo que é essencial para a vida do demandatário e de sua família, mas que pode torná-lo novamente beneficiário, na medida em que se desvincula deste ato de demandar o próprio desejo do demandatário de ser outra coisa, que não beneficiário, sendo ele e sua família esquadrinhados e subjugados em linhas de vulnerabilidade que determinarão seu modo de circular por meio dos programas, projetos e serviços disponibilizados pela Assistência Social. Estas modalidades de esquadrinhamento encontram-se nos formulários de atendimento, tais como o Cadastro Único para Programas Sociais do Governo Federal (Cadastro Único) e a ficha de inscrição para o Programa Universidade Para Todos (ProUni), entre outros. Essas modalidades tendem a classificar os sujeitos que buscam seus direitos, por meio da renda per capita, da constituição familiar, das condições de moradia e da idade, dentre outros aspectos. Tais especificações de esquadrinhamento da realidade dos sujeitos que buscam o atendimento os deslocam para lugares e ações específicas da Assistência Social. Mesmo demandando um direito, o sujeito é deslocado para o campo do benefício, uma vez que suas especificidades são alocadas em "blocos" que o caracterizam em números.

Aqui nesta análise, ser demandatário é reconhecer-se como cidadão de direitos e exigir/reivindicar que Ihe sejam disponibilizados, mas também é reconhecer-se beneficiário, pelo modo como se configura o acesso neste jogo de forças, em que se estabelecem diferentes diretrizes e formulários para acesso à Assistência social.

\title{
Ontologias e direito
}


A partir desse itinerário cartográfico, começa-se a delimitar questões relativas ao direito e à possibilidade de olhá-lo de diferentes lugares e modos. Direito entendido como tudo aquilo que regula a vida em sociedade e que, além dos discursos dos direitos naturais, perpassa os infinitos jogos de poder que se estabelecem em determinado tempo e lugar, coadunando possibilidades de vida para uns e para outros, e possibilidades de morte para uns e para outros. Assim,

[...] é o direito um sistema de disciplina social fundado na natureza humana que, estabelecendo nas relações entre os homens uma proporção de reciprocidade nos poderes e deveres que lhes atribui, regula as condições existenciais dos indivíduos e dos grupos sociais e, em consequência, da sociedade mediante normas coercitivamente impostas pelo poder público (RÁO, 1999, p. 55).

Aqui, direito é compreendido como aquele de terceira geração, ou seja, os direitos sociais, especificamente aqueles consolidados a partir da implantação de Políticas Públicas voltadas para a Assistência Social. Destarte, só é possível falar de direitos sociais em uma sociedade específica, em um tempo e espaço delimitados, em uma conformação jurídica própria que, mesmo se aproximando de outras realidades, emerge em contextos sociais onde a comparação não pode ser realizada.

O projeto de Estado, conformado pelo ideário que Ihe dá sustentação, configura como a conquista dos direitos foi ganhando visibilidade na sociedade. Assim, o Estado liberal foi campo dos direitos civis e políticos; o Estado social, dos direitos sociais; e o conformado pelo ideário neoliberal, ao retomar os direitos individuais, pauta-se na lógica da desregulamentação dos direitos sociais. Na base dessas propostas, está um vasto campo de lutas da sociedade e dos homens para verem atendidas suas demandas de liberdade, autonomia e igualdade (COUTO, 2006, p. 61).

Direito, consubstanciado, como afirma Bobbio (2004), a partir de um sistema de normas, só existindo na medida em que há direitos e também deveres. Nessa relação direitos e deveres -, já é possível aproximar as configurações dos jogos que se estabelecem na Política de Assistência Social no Brasil, em que, para se acessar o direito a renda mínima, há que se cumprirem muitos deveres. Em alguns momentos específicos da história do Brasil, como afirma Couto (2006, p. 92), a relação que se explicita é o direito pela via da "dádiva e do compadrio".

No campo dos direitos, embora alguns já estivessem escritos na Constituição [1891], a relação entre o povo, a elite e os governos fluía através da ótica persistente da dádiva e do compadrio. Desse modo, a novação de direito foi substituída pela 
concessão, que tem como compromisso fundante a manutenção do status quo. $E$ essa característica atravessa os vários movimentos e regimes políticos da sociedade brasileira, construindo uma relação de dependência entre quem detém o poder, a terra, os meios de produção e o capital versus aqueles que vivem e sobrevivem à margem da riqueza socialmente produzida e que têm incorporado a "concessão social" como demarcadora de sua vida e o "direito social" como categoria intangível pela ótica da cidadania (COUTO, 2006, p. 92).

Falar sobre o sujeito de direitos remete a diferentes possibilidades de reconhecê-lo. Aqui, o que se pretende é problematizar o direito indo além da romantização de que todos o possuem por sua simples existência humana em sociedade. Faz-se um movimento de pensar o direito a partir de diferentes perspectivas, quais sejam: da conquista, da doação, do acesso e da posse.

Essas perspectivas foram consubstanciadas a partir da análise do processo de implantação/implementação da Política de Assistência Social brasileira, principalmente em seu percurso histórico, em que ela perpassa todas aquelas perspectivas - um movimento que pode ser específico, mas que é também uma forma de observar os diferentes movimentos que o sujeito da assistência social pode realizar. Não são movimentos propostos aprioristicamente; eles só são possíveis no momento em que o beneficiário/demandatário acessa e circula entre as diferentes políticas que integram a Proteção Social, seja ela básica ou especial. São movimentos espontâneos, mas que possibilitam diferentes formas de compreender uma ontologia do beneficiário/demandatário e os ínfimos processos de subjetivação que lhe permitem acessar diferentes direitos sociais.

Considerar o direito a partir da concessão possibilita um reencontro com a própria história da Assistência Social, estruturada inicialmente pela benesse, e remete a um sujeito que "concede" e a outro que "recebe". Em termos de organização da atual Política de Assistência Social, tem-se o Estado, que concede ao sujeito beneficiário diferentes possibilidades de acesso aos direitos sociais via elaboração e implantação de Políticas Sociais. A concessão dá-se em meio a um regime jurídico específico em que, para que o sujeito "receba" a concessão do direito, deve, a priori, submeter-se a um regime de veridicção de pobreza, pautado essencialmente pela comprovação de sua miséria, por meio do preenchimento de formulários específicos para cada direito que necessita acessar. Nesse regime de verdade, pautado, então, pela perspectiva da norma, terá acesso à concessão do benefício/direito aquele que puder comprovar sua marginalidade diante da Política Social que necessita acessar. 
Problematizar o direito pela via da conquista leva a um sujeito ativo no contexto dos diferentes Movimentos Sociais que têm como pauta de ação o acesso aos direitos sociais específicos. Aqui, não só o direito em si é colocado em análise, mas, sobretudo, os movimentos de deslocamento que as demandas de determinado grupo social realizam para adentrar na agenda política do Estado. Mesmo tomados por uma organização que emerge da própria mobilização popular, há, no interior desses grupos, jogos de poder antagônicos que possibilitam que um direito tenha maior visibilidade que outro, ou mesmo que um grupo específico tenha maior visibilidade que outros.

Tal fato dependerá de um movimento maior, que não parte apenas desses Movimentos Sociais organizados, mas do movimento dos jogos de poder que se estabelecem entre os agentes políticos, o Estado e os Movimentos Sociais. Como afirma Gohn (2010, p. 173),

[...] a identidade política dos movimentos sociais não é única, ela pode variar em contextos e conjunturas diferentes. E muda porque há aprendizagens e a produção de novos saberes, que geram consciência e possibilidades de entendimento. $\mathrm{Na}$ maioria das vezes os sujeitos participantes dos movimentos sociais têm aprendido a fazer leituras de mundo, identificar projetos diferentes ou convergentes, gerados como respostas às demandas socioeconômicas que eles fazem. Aprendem também com as respostas, estatais ou da sociedade, às suas demandas [...].

Para isso, considera-se um determinado tempo-espaço que também permitirá que determinados assuntos se sobreponham a outros e que, por conseguinte, tenham maiores chances de obtenção de resposta em forma de implantação de Políticas Públicas.

No que se refere à análise a partir da doação, há uma nova possibilidade de operar com o direito. Este já não é mais direito de todos os sujeitos por sua própria natureza ou por suas necessidades; o direito é reconfigurado/personificado em figuras que circulam nas diferentes modalidades das Políticas Sociais, principalmente aquelas disponibilizadas na Assistência Social. Tomar o direito pela benesse implica tornar o próprio direito um favor. Já não se trata do direito em um determinado regime de normas jurídicas, nem de esquadrinhamento das necessidades em inúmeros formulários, mas do direito como uma "moeda de troca", "compra de votos", como ação extremamente paliativa que, ao personificar-se em um agente político (normalmente um ator político), coloca em evidência a própria história de constituição da Política de Assistência Social no Brasil, consolidada por ações de caridade. 
Já no direito analisado a partir do acesso, há um duplo movimento, que diz respeito a ter direitos e a acessá-los efetivamente. Nos regimes de veridiç̧ão que se colocam na sociedade brasileira, há inúmeros direitos que, na letra da lei, devem ser disponibilizados a todos os sujeitos. Todavia, os discursos que interpelam os sujeitos de direitos fazem pensar sobre o direito em si, mas também sobre o acesso efetivo a determinado direito. Desse modo, ao observarem-se uma determinada sociedade, um tempo e espaço específicos, é possível encontrar movimentos dispersos de acesso efetivo a determinado direito e às prerrogativas dos direitos como naturais de cada indivíduo. Falar do direito pelo acesso permite problematizar as desigualdades sociais estabelecidas nesse jogo de direito e acesso. Dessa maneira, todos têm direitos, mas nem todos conseguem acessá-los.

Nesse movimento de "ter direitos e acessar direitos", chega-se à análise do direito como posse. A análise do direito a partir da posse só pode ser evidenciada em uma sociedade cujas bases de relações se deem pela via do neoliberalismo. Operar com o neoliberalismo para esta análise é colocar em foco os diferentes processos de subjetivação que possibilitam que cada indivíduo se torne um empreendedor de si mesmo. É também considerar as práticas neoliberais como grade de inteligibilidade que permite que cada movimento do sujeito seja avaliado a partir da perspectiva econômica e que cada um seja responsável por si mesmo.

Mesmo que não seja pelas superfícies, mas por diferentes encontros rizomáticos, colocar o direito em análise a partir de termos distintos torna possível afirmar que o direito não é para todos; ou seja, que o sujeito é de direito, mas o direito nem sempre é do sujeito. Permite problematizar diferentes modalidades de alcançar os direitos prescritos nos mais diversos regimes jurídicos e normativos estabelecidos na sociedade contemporânea e, acima de tudo, possibilita encontrar múltiplos movimentos de subjetivação dos sujeitos para o acesso aos direitos.

Este processo subjetivação dos sujeitos de direitos diz respeito aos movimentos que o sujeito de direito realiza para alcançar seus direitos, mas também para sobrepor-se a todas as limitações de acesso aos direitos que lhe são postas no cotidiano. Há, portanto, redes de encontros entre os sujeitos e as Políticas Sociais, e os direitos fazem emergir inúmeras modalidades de o sujeito reconhecer-se, não só como sujeito de direito, mas também como beneficiário e demandatário das Políticas Sociais, em especial daquelas direcionadas à Assistência Social. 
Em uma primeira análise, busca-se conceituar beneficiários e demandatários. Cabe ressaltar que, nos dicionários específicos de Assistência Social, ou mesmo na própria Política Nacional de Assistência Social, não há definição destes termos. Eles apenas aparecem em momentos distintos, em diferentes políticas da Assistência Social. Rastreando outros caminhos, a busca deu-se em um dicionário de português virtual, tendo sido encontradas algumas definições que podem auxiliar na problematização do uso destas terminologias para indicar os usuários da Assistência Social. A escolha do dicionário foi aleatória - o primeiro que apareceu foi o escolhido para consulta. Todas as definições apresentadas a partir de agora foram retiradas do "Dicio-Dicionário on-line de Português". Para o termo beneficiário, encontrou-se a seguinte definição: "Diz-se do herdeiro a quem se concedeu benefício de inventário; Que se beneficia de alguma coisa, de uma vantagem, de um favor etc" (DICIO, 2018).

$\mathrm{Na}$ análise desta definição, encontram-se dois elementos que, para este estudo, já denotam o caráter da benesse, enraizado nos discursos sobre os benefícios da Assistência Social. O primeiro pode ser evidenciado no termo herdeiro, que possibilita inferir que o direito vai sendo "herdado", em um movimento contínuo de um sujeito a outro de uma mesma família. Isso conduz à questão do benefício a partir da contribuição, ou seja, quem contribuiu terá o benefício como uma "herança" gestada e, depois, distribuída pelo Estado. Pode também ser analisado pela perspectiva do próprio Estado como doador, ao possibilitar uma "vantagem, um favor" a quem necessitar.

Talvez, em um primeiro momento, debruçar-se sobre este termo não faça nenhum sentido, uma vez que todos os benefícios socioassistenciais gestados pelo Estado fazem parte de uma Política Pública fundamentada pelo direito aos mínimos sociais para sobrevivência. Porém, toma outro significado ao ser analisado a partir da própria história da Assistência Social, intrincada com a benesse, com o favor. Tal fato, em si mesmo, já desconfigura o direito aos mínimos sociais e transporta-o para ações fragmentadas, paliativas, cujos objetivos não são prioritariamente a organização do acesso aos direitos sociais, mas, essencialmente, um regime de veridicção que não permite que o beneficiário se veja como um detentor de direitos, mas um receptor de favores. Isso implica, neste estudo, o modo como este sujeito vai deslocar-se no acesso aos diferentes serviços prestados pela Assistência Social e, principalmente, como ele vai colocar-se neste processo: não como sujeito de direito, mas como sujeito do benefício. Nesse sentido, este sujeito vai se limitando aos 
bens/serviços/direitos disponibilizados a partir das Políticas Públicas e é esquadrinhado a partir dos inúmeros formulários que deve preencher. Os direitos do sujeito vão se dividindo a partir de suas necessidades mais urgentes. Não se trata do sujeito em sua totalidade, mas de suas vulnerabilidades.

No que se refere ao termo demandatário, não foi encontrado uma definição nos dicionários específicos de Assistência Social, assim como em dicionários on-line. O termo que mais se aproxima, que se tomou para análise, é demandar, cuja definição é: "Pedir, reclamar ou conseguir algo por meio de uma solicitação, pedido [...] [jurídico] Fazer um requerimento pela via judicial, legal; requerer [...] Fazer uma pergunta, uma indagação, perguntar" (DICIO, 2018).

Imediatamente, ao se ler tal definição, compreende-se um movimento que é do sujeito da ação. Não mais aquele que "herda" um benefício, o demandatário é quem vai em busca de algo. Desta feita, há um movimento de deslocamento - não só do próprio sujeito em "ir até algum lugar", como também do conhecimento. Isto é apontado porque é por meio do conhecimento, de saberes múltiplos, que o demandatário pode "requerer" seu direito. Não mais subjetivado pelo "favor do benefício" que lhe é concedido por outrem, o demandatário está em outro patamar de conhecimento, pois se reconhece no próprio direito, nas práticas que se estabelecem por meio das Políticas Públicas. Ao demandar, não aceita o favor, mas requer um direito, e isso tende a alterar os processos de acesso aos direitos sociais.

Ao beneficiário, caberá receber o benefício e acatar as determinações de quem o atende. Não quer dizer que o beneficiário não seja capaz de pensar ou de ter conhecimento suficiente para demandar. Quer-se, por outro lado, problematizar este processo de subjetivação do sujeito da Assistência Social, que, na maioria das vezes, chega até ela pela via da benesse, mas, com o tempo, vai circulando e tomando conhecimento de outras formas de acessar bens/serviços/direitos. Ao produzir uma gama expressiva de conhecimentos sobre as Políticas Públicas, bem como sobre o processo de acessar bens/serviços/direitos, o próprio sujeito da Assistência Social põe em xeque a benesse sobreposta nas intervenções das práticas estabelecidas no atendimento destas ações governamentais.

Ao subjugar-se a partir do demandatário, o sujeito da Assistência Social produz rupturas no modo de conceber e disponibilizar acesso a bens/serviços/direitos. Não aceita ser conectado à rede de favores e exige o cumprimento de direitos estabelecidos em Lei. Essa ruptura vai produzindo outras práticas e discursos sobre os direitos sociais. 
Para demandar, o sujeito da Assistência Social é colocado em um regime de veridiç̧ão, como o beneficiário, a fim de comprovar suas reais e principais necessidades. Todavia, ao ter em vista o direito, e não o favor, concebe de formas particulares o modo de organização das Políticas Públicas, questiona determinadas práticas; consegue vislumbrar "brechas" para acessar o direito que lhe é resguardado legalmente, mas que na prática lhe foi negado por um longo tempo. O demandatário, nesta pesquisa, é o empreendedor de si mesmo. É o Homo oconomicus do neoliberalismo, que governa sua vida a partir do gerenciamento de conhecimentos adquiridos durante o seu próprio caminhar pela Política de Assistência Social e outras Políticas Públicas que se interligam no acesso a bens/serviços/direitos. Não se contenta com o mínimo, quer apenas que a totalidade de seus direitos seja cumprida.

\section{Considerações finais}

As figuras do beneficiário e do demandatário percorrem diferentes modalidades de acesso e permanência nas Políticas Sociais, subjetivando-se em figuras capazes de alterar a própria Política, em virtude de suas demandas e de seu conhecimento. Assim, foi possível reafirmar que o sujeito beneficiário e o sujeito demandatário não são sujeitos diferentes, mas podem ser o mesmo sujeito, que, por meio do reconhecimento de suas necessidades a direitos/bens/serviços da Política de Assistência Social, reformula modos de acessar e permanecer acessando os direitos dispostos naquela Política.

O fato de demandar nem sempre é visto com "bons olhos" por aqueles que atuam nas diferentes Políticas Públicas, principalmente na Assistência Social, tendo em vista o "gene da benesse" que ainda circula em todas as esferas de atendimento daquela Política. Quando o demandatário passa a requerer seus direitos por meio de seus conhecimentos sobre a própria Política, vai sendo denominado por outros termos. Já não é beneficiário, nem demandatário - é o "sujeito que burla". Burlar, aqui nesta pesquisa, é a ação do sujeito da Assistência Social, que, reconhecendo-se como sujeito de direito e tendo o conhecimento específico de determinada política pública, passa a negociar com a norma, transformando-a em multiplicador de direitos e não em limitador de necessidades.

Nesse sentido, o sujeito da Assistência Social passa a agir de modos diferentes para que consiga acessar bens/serviços/direitos. Consegue, por meio da própria Política, multiplicar as formas de acesso e força outros movimentos da Política para tentar capturá-lo. 
É possível afirmar, então, que os movimentos dos demandatários possibilitam que se atualizem as normas que estabelecem os critérios de elegibilidade das inúmeras políticas sociais, não no sentido de ampliar as possibilidades para que outros sujeitos acessem os bens/serviços/direitos, mas para capturar os diferentes movimentos que o sujeito realiza, de tal modo que é constante a atualização dos sistemas para "barrar", "pegar", "vigiar" os sujeitos da Assistência Social e evitar que "burlem" as normas.

\section{Referências}

BELO HORIZONTE. Prefeitura Municipal. Secretaria Municipal Adjunta de Assistência Social. Dicionário de termos técnicos da assistência social. Belo Horizonte: ASCOM, 2007. p. 132.

DICIO. Beneficiário In: Dicionário Dicio. Disponível em: www.dicio.br/beneficiários. Acesso em: 31 out. 2018.

BOBBIO, N. A era dos direitos. 5. ed. Apresentação de Celso Lafer. Rio de Janeiro: Elsevier, 2004.

BRASIL. Política Nacional da Assistência Social 2004. Ministério do Desenvolvimento Social e Combate à Fome. Secretaria Nacional de Assistência Social: Brasília, 2004.

Lei no 12.435, de 6 de julho de 2011. Altera a Lei no 8.742, de 7 de dezembro de 1993, que dispõe sobre a organização da Assistência Social. Diário Oficial da União: Brasília, 2011. Disponível em: http://www.planalto.gov.br/ccivil 03/ Ato2011-2014/2011/Lei/L12435.htm. Acesso em: 21 mar. 2019.

COUTO, B. R. O direito social e a assistência social na sociedade brasileira: uma equação possível? 2. ed. São Paulo: Cortez, 2006.

DICIO. Demandar In: Dicionário Dicio. Disponível em: www.dicio.br/demandar. Acesso em: 31 out. 2018.

FERNANDES, R.; HELLMANN, A. Dicionário crítico: política de assistência social no Brasil. Porto Alegre: Ed. UFRGS, 2016.

FOUCAULT, M. Nascimento da biopolítica (1978-1979). São Paulo: Martins Fontes, 2008.

GOHN, M. da G. Movimentos sociais e redes de mobilizações civis no Brasil contemporâneo. Petrópolis: Editora Vozes, 2010.

RÁO, V. O direito e a vida dos direitos. 5.ed. São Paulo: Editora Revista dos Tribunais, 1999.

MAIA, S. F. Problematizando o acesso às políticas sociais no campo da educação superior. Orientação Anita Guazzelli Bernardes, 2018. Tese (Doutorado em Psicologia) - Universidade Católica Dom Bosco. 
PRADO FILHO, K.; TETI, M. M. A cartografia como método para as ciências humanas e sociais. Barbaroi, Santa Cruz do Sul, no 38, p. 45-49, jun. 2013. Disponível em: <http:// pepsic.bvsalud.org/scielo.php?script=sci_arttext\&pid=S0104-65782013000100004 \&lng=pt\&nrm=iso>. Acesso em: 21 mar. 2019.

SILVA, M. B. Usuários. In: FERNANDES, R.; HELLMANN, A. (Org.). Dicionário crítico: política de assistência social no Brasil. Porto Alegre: Ed. UFRGS, 2016. p. 293-294.

Recebido em: 08/08/2019

Aceito em: 25/03/2020 